\title{
BMJ Global Health How to combat efforts to overturn bans on electronic nicotine delivery systems: lessons from tobacco industry efforts during the 1980s to open closed cigarette markets in Thailand
}

\author{
Roengrudee Patanavanich (D) , ${ }^{1,2}$ Stanton A Glantz (D) ${ }^{1}$
}

To cite: Patanavanich $\mathrm{R}$, Glantz SA. How to combat efforts to overturn bans on electronic nicotine delivery systems: lessons from tobacco industry efforts during the 1980 s to open closed cigarette markets in Thailand. BMJ Global Health 2021;6:e004288. doi:10.1136/ bmjgh-2020-004288

\section{Handling editor Eduardo} Gómez

Received 24 0ctober 2020 Revised 23 December 2020 Accepted 6 January 2021

Check for updates

(C) Author(s) (or their employer(s)) 2021. Re-use permitted under CC BY-NC. No commercial re-use. See rights and permissions. Published by BMJ.

${ }^{1}$ Center for Tobacco Control Research and Education, University of California San Francisco, San Francisco, California, USA

${ }^{2}$ Department of Community Medicine, Mahidol University Faculty of Medicine Ramathibod Hospital, Bangkok, Thailand

Correspondence to Dr Roengrudee Patanavanich; kade.patanavanich@gmail.com

\section{ABSTRACT}

Until 1990, it was illegal for transnational tobacco companies (TTCs) to sell cigarettes in Thailand. We reviewed and analysed internal tobacco industry documents relevant to the Thai market during the 1980s. TTCs' attempts to access the Thai cigarette market during the 1980 s concentrated on political lobbying, advertising and promotion of the foreign brands that were illegal to sell in Thailand at the time. They sought to take advantage of the Thai Tobacco Monopoly's (TTM) inefficiency to propose licencing agreements and joint ventures with TTM and took advantages of unclear regulations about cigarette marketing to promote their products through advertising and sponsorship activities. After their initial efforts failed, they successfully lobbied the US to impose trade sanctions to liberalise Thailand's market. Similar to the situation for cigarettes in the 1980s, since 2017, Philip Morris International has worked in parallel with a pro-e-cigarette group to pressure Thailand's government to allow sales of electronic nicotine delivery systems (ENDS; including e-cigarettes and heated tobacco products), knowing the products were illegal under Thai law. Health advocates and government authorities should be aware of past TTCs' tactics for cigarettes and anticipate that TTCs will attempt to use international trade law to force markets open for ENDS if their domestic efforts fail.

\section{INTRODUCTION}

By 2014, transnational tobacco companies (TTCs) started selling heated tobacco products (HTP; also called 'heat-not-burn') that heat a mixture of ground tobacco and additives to generate an inhaled nicotine aerosol. ${ }^{1}$ Philip Morris International (PMI) introduced its HTPs to Thailand in 2017, knowing the products were illegal under Thai law and worked in parallel with a pro-e-cigarette group (ENDS Cigarette Smoke Thailand) in efforts to force the Thai market to open to electronic nicotine delivery systems (ENDS), including HTP and e-cigarettes, products that heat
Summary box

Since 2017, Philip Morris International has worked in parallel with a pro-e-cigarette group in efforts to force the Thai market to open to electronic nicotine delivery systems (ENDS).

- As of January 2021, ENDS were still illegal in Thailand.

- Tobacco industry's efforts to open ENDS markets are like their past efforts to liberalise closed cigarette markets during the 1980s.

- The transnational tobacco companies (TTCs) attempts to open Thailand's closed cigarette market in the 1980s started with domestic political lobbying, seeking joint ventures with Thailand's state-run tobacco monopoly and advertising and sponsorships.

- When these efforts failed, the TTCs convinced the US to use international trade sanctions to successfully open the Thai market.

- Understanding tactics TTCs used in the past to access Thailand's closed market for cigarettes will help policymakers recognise and reject similar approaches currently used by the TTCs in their efforts to introduce ENDS to Thailand and countries that currently ban them.

-While continuing to defend ENDS bans domestically, health advocates should take care to lay the foundation for fighting international trade claims as a future industry tactic to open markets to ENDS and other new tobacco products.

a nicotine solution to generate an inhaled nicotine aerosol. ${ }^{2}$ Efforts to introduce these currently illegal products into Thailand's market is reminiscent of efforts in the $1980 \mathrm{~s}$ to open the Thai market to international cigarettes. From 1939, when the Thai government created the Thai Tobacco Monopoly (TTM) under the Ministry of Finance Excise Department, ${ }^{3}$ until 1990 when the US used trade sanctions under the General Agreement on Tariffs and Trade (GATT) to force open the 
Thai cigarette market, ${ }^{4}$ Thailand was closed to legal sales by TTCs. TTCs first tried to enter Thailand by seeking joint ventures and licencing agreements with the $\mathrm{TTM}^{5}$ as well as sports sponsorship and monitoring cigarette smuggling. ${ }^{67}$ After these local efforts failed, the TTCs successfully switched to lobbying the US government to use trade sanctions to force open the Thai cigarette market.

This study uses internal tobacco industry documents to analyse TTC activities and relationships with Thai government officials in the 1980s to learn how TTCs worked to gain access into Thailand's closed cigarette market. We searched the Truth Tobacco Documents Library (https://www.industrydocuments.ucsf.edu/tobacco/) between September 2019 and April 2020 for documents dated 1980-1990 with the keyword 'Thailand'. We found 4144 documents in British American Tobacco's (BAT) collection, 2162 documents in Philip Morris's (PM) collection and 1627 documents in RJ Reynolds's (RJR) collection. We then used standard snowball searches ${ }^{8}$ using the names of individuals, organisations and key events mentioned in the documents, examining adjacent documents 'previous and next Bates' and 'more like this'. These searches resulted in 491 relevant documents (372 from BAT, 114 from PM, 4 from RJR and 1 from Tobacco Institute). We also reviewed TTM annual reports and news articles from Thai newspapers during the 1980s available from the National Library of Thailand's archive collections to verify relevant events.

The main limitation of this paper is it excludes opinions from Thai tobacco control experts because Thai tobacco control organisations formed during the Thai-US trade dispute around 1986. Thus, events before this period are generally unknown to Thai tobacco control experts.

We reviewed the documents using a chronological analysis and analysed the documents using the standard thematic analyses ${ }^{9}$ to describe TTCs' strategies to access the Thai cigarette market. The specific major theme coded were: (1) TTCs' local efforts, (2) TTCs' international efforts through trade action and (3) TTCs' preparation for the market opening. Then, we applied these findings to discuss the current tobacco industry's efforts to open ENDS markets.

\section{STRATEGIES ADOPTED BY TTCS TO ACCESS THE THAI CIGARETTE MARKET}

In the 1970s, TTM modernised its production facilities to compete with international brands ${ }^{10}$ and started importing foreign cigarettes to stop smuggling and satisfy upper-class smokers and tourists. ${ }^{11}$ TTCs responded with three concurrent strategies to access the Thai market: licencing agreements and joint ventures with TTM and, preferably, opening the Thai market to imported cigarettes. ${ }^{12}{ }^{13}$ After these three strategies failed, they successfully lobbied the US to impose trade sanctions to liberalise Thailand's market. Table 1 documents four strategies used by TTCs between 1975 and 1991 .
Local efforts of TTCs to enter the Thai market Licencing agreements

TTCs sought licencing agreements with TTM that would allow it to produce their foreign cigarette brands, believing that licencing allowed the TTCs to pre-empt competition, increase the sale of leaf to TTM, secure an opportunity for a joint venture with TTM and ultimately legalise imports. ${ }^{13-15}$ During the 1980s, BAT attempted to licence State Express $555^{1617}$ and PM attempted to licence Marlboro. ${ }^{13} 15$ TTCs approached TTM board members and high-level government officials through surrogates, arguing that the licencing would benefit TTM by increasing usage of Thai leaf, provide access to modern production technology to internationalise TTM and profitability, reduce smuggled tobacco and increase in farmers' incomes. ${ }^{15} 18$ However, licenced manufacture was deferred in late 1984 due to a currency devaluation and because the Thai government was under pressure to impose restrictions on the import of luxury goods. ${ }^{19}$

\section{Joint ventures with TTM}

TTCs sought joint ventures with TTM between 1981 and 1987 when TTM considered building a new factory outside Bangkok to avoid union resistance towards multishift work and increase production from a non-union plant. ${ }^{20}$ The Thai government was also interested in commercial ventures to modernise TTM and combat smuggling of foreign cigarettes. ${ }^{21} 22$ TTCs tried to connect with cabinet members, business executives and other influential Thais and hired politically influential local agents to help them connect with TTM and the government. ${ }^{23-29}$ All these attempts failed, mainly because TTM's union opposed foreign involvement out of concern that its inefficiencies would be uncovered and consumer preference would swing to foreign brands, causing further loss of business and overtime. ${ }^{30-32}$

\section{Legal import}

Legal import was the TTCs' preferred option, and they made several attempts to achieve it. ${ }^{13}$ TTCs' local efforts to liberalise Thailand's market failed because strong oppositions from TTM's union and Thai tobacco control advocates, led by the Thai Anti-Smoking Campaign Project (formed in 1986) and the National Committee for the Control of Tobacco Use, an entity appointed by the Cabinet under the 1988 National Tobacco Control Plan. ${ }^{4}$ The tobacco control advocates successfully submitted letters to the prime minister opposing legal imports. ${ }^{4}$

\section{International efforts through trade action to open the Thai cigarette market}

After many years of unsuccessful efforts to gain access to the Thai market, TTCs turned to lobbying the US government through the US Trade Representatives (USTR) to levy trade sanctions against Thailand and force its market open. ${ }^{33} 34$ TTCs were confident they could open the Thai market. The executive vice president of PMI stated at a PM board meeting in August 1989, 'We anticipate 
Table 1 TTCs' local efforts to enter the Thai market: timeline of key events

\begin{tabular}{ll}
\hline Date & Event \\
\hline $1975-1979$ (L) & $\begin{array}{l}\text { BAT proposed a licencing agreement with TTM for State Express 555, but the project was shelved in August 1979 } \\
\text { after the prime minister, who was to be the signatory, lost his office. }{ }^{16} 17\end{array}$ \\
September 1978 (I) & $\begin{array}{l}\text { The cabinet proposed legal imports to solve foreign cigarette smuggling but disapproved imported cigarettes by } \\
\text { private parties and allowed TTM to solely import foreign cigarettes and modernise the production to complete with }\end{array}$
\end{tabular}
international brands. ${ }^{10}$

$\begin{array}{ll}\text { March } 1981(\mathrm{~J}) & \begin{array}{l}\text { BAT proposed a manufacturing company to TTM with } 50 \% \text { Thai government ownership (BAT would provide free } \\ \text { shares and benefits to the government) with BAT returning all assets to the Thai government after } 15 \text { years. }\end{array} \\ \text { July } 1981(\mathrm{~J}) & \begin{array}{l}\text { TTM's board rejected BAT's proposal. } \\ \text { that }\end{array} \\ \text { that its inefficiencies would be uncovered and consumer preference would swing to foreign brands, causing further } \\ \text { loss of business. }\end{array}$

August $1982(\mathrm{~L}) \quad$ The Deputy Secretary of the General Office of the Prime Minister and Chairman of the Milk Board approached BAT
about TTM producing BAT's State Express 555 brand under a licencing agreement and with technical assistance from
BAT. ${ }^{14} 17$
BAT responded to the Deputy Secretary that it expected to secure this licencing deal by $1983 .^{16} 17$

January $1983(\mathrm{~L}) \quad$ BAT approached TTM board members through surrogates to convince them of the benefits of 555 licenced manufacture. $^{18}$ $\begin{array}{ll}\text { November } 1983(\mathrm{~L}) & \begin{array}{l}\text { BAT regularly visited the new TTM Chairman (and also an Undersecretary in the Ministry of Finance) and managing } \\ \text { director, believing they were open to foreign involvement. }\end{array} \\ \text { January } 1984 \text { (L) } & \begin{array}{l}\text { BAT offered } 10 \text { million } 555 \text { sticks to TTM to help it meet a market shortage due to a prolonged strike of TTM's union } \\ \text { and strengthen TTM's negotiating position. }{ }^{69} \text { BAT also offered technical support to improve manufacturing, including }\end{array}\end{array}$ expertise in producing low-tar cigarettes. ${ }^{70}$

\begin{tabular}{|c|c|}
\hline February $1984(J)$ & $\begin{array}{l}\text { PM Chairman Hamish Maxwell had dinner in New York with the Thai Ambassador to the United Nations to discuss } \\
\text { how the ambassador could help PM enter the Thai market. }{ }^{71} \text { The president of PM Asia told Maxwell that PM was } \\
\text { willing to export Marlboro to Thailand but that PM thought this option would not be possible and was willing to } \\
\text { licence a PM trademark to TTM, proposing a joint brand with TTM which, if successful, would lead to legal imports of } \\
\text { Marlboro and, if sales goals were met, move to licencing TTM to manufacture Marlboro. }{ }^{13}{ }^{15}\end{array}$ \\
\hline March $1984(J)$ & RJR submitted a proposal for licencing and joint venture with TTM to the Thai government. ${ }^{47}$ \\
\hline May $1984(J)$ & $\begin{array}{l}\text { PM submitted a proposal to the Thai government for a joint brand }{ }^{21} \text { followed by licencing TTM to manufacture } \\
\text { Marlboro. }{ }^{15}\end{array}$ \\
\hline June $1984(\mathrm{~J})$ & BAT submitted a proposal to the Thai government for licencing and a joint venture with TTM. ${ }^{47}$ \\
\hline 1984-1985 (J) & $\begin{array}{l}\text { PM connected with cabinet members, business executives and other influential Thais }{ }^{23-26} \text { but was unable to open } \\
\text { the Thai market. In } 1985, \text { PM spent } \$ 150000 \text { to sponsor Ambassadors of Opera in many Asian countries including } \\
\text { Thailand to gain 'PM high visibility' and direct access to top-level government officials and other influential Thais. } \\
\text { During PM's } 1985 \text { board meeting, PM International Executive Vice President Richard Snyder emphasised PM's } \\
\text { success in approaching key policymakers: } \\
\text { 'As regards Thailand, we have had a number of corporate affairs successes this year, including sponsorship of } \\
\text { "Ambassadors of Opera" in Bangkok, and acting as host for a day to the Queen during a recent visit to New York. We } \\
\text { have met many prominent government members and our challenge is now to make the best use of these contacts to } \\
\text { establish a business in Thailand'. }{ }^{28}\end{array}$ \\
\hline December 1984 (I) & $\begin{array}{l}\text { The director general of the Excise Department recommended legal imports to the Ministry of Finance by appointing } \\
\text { distributors independently of TTM to handle sales. } \\
\text { The recommendation on legal imports was stalled due to currency devaluation in late } 1984 \text { as well as the government } \\
\text { being under pressure to impose restrictions on the import of luxury goods. }{ }^{19}\end{array}$ \\
\hline January $1985(J)$ & $\begin{array}{l}\text { All TTC proposals for joint ventures were turned down because the Minister of Finance preferred state-owned } \\
\text { business, joint-brand cigarettes contradicted the 'Buy Thai' campaign, and because TTM worker opposition to foreign } \\
\text { investment in the domestic market. }\end{array}$ \\
\hline December 1986 (I) & $\begin{array}{l}\text { US delegates (led by Congressman Lester Wolff) came to Thailand and met with the Prime Minister to pressure } \\
\text { Thailand to purchase US-made cigarettes and to enter into a bilateral trade agreement similar to those the USA had } \\
\text { concluded with Japan, South Korea and Taiwan. }{ }^{7576}\end{array}$ \\
\hline $1987-1988(J)$ & $\begin{array}{l}\text { US government pressure on Thailand to open its market caused the Thai Minister of Finance to announce a new TTM } \\
\text { cigarette factory would be built in Chiang Mai as a joint venture with a foreign manufacturer. }{ }^{77} 78 \\
\text { TTCs resubmitted joint venture proposals to the Thai government. } \\
\text { To enhance the opportunity for this joint venture, TTCs hired politically influential local agents to help them connect } \\
\text { with TTM and the government. }{ }^{29} \text { BAT hired Des Kennedy of the White Group, }{ }^{81} \text { who had a long-term business } \\
\text { relationship with TTM }{ }^{82} \text { BAT also hired Verapaul Mudamura, a member of the Thai House of Representatives (who had } \\
\text { a close connection with the Deputy Comptroller-General in the Ministry of Finance who was his co-owner of a small } \\
\text { firm of tobacco dealers near Chiang Mai) } \\
\text { According to BAT, PM appointed the family of a Deputy Prime Minister and RJR appointed a family of a private bank in } \\
\text { Thailand (Thai Danu) whose Chairman was an ex-prime minister and whose son was a deputy prime minister. }{ }^{29} 81\end{array}$ \\
\hline
\end{tabular}

Continued 


Table 1 Continued

January 1988 (J) Event

The cabinet authorised the Ministry of Finance and TTM to select a foreign company to build a cigarette plant with the condition that all its production be sold to $\mathrm{TTM}^{85}$

Despite allowing a new cigarette factory to be built, the prime minister asked the Ministry of Public Health (MOPH) to launch a plan for tobacco control and the first National Tobacco Control Plan (drafted by Dr Hatai Chitanondh, deputy director general of the Department of Medical Services in the $\mathrm{MOPH}^{4}$ ) was approved by the cabinet in April 1988, ${ }^{48185}$ including an advertising ban to protect Thailand from future TTC invasions. ${ }^{4}$

\begin{tabular}{|c|c|}
\hline July 1988 (J) & $\begin{array}{l}\text { The joint venture for the new cigarette factory was delayed due to a general election and later shelved after the new } \\
\text { prime minister and his new government came to power in July 1988, because they did not want to deal with the TTM } \\
\text { union, who feared losing overtime. }{ }^{31} 32\end{array}$ \\
\hline August $1988(\mathrm{l})$ & $\begin{array}{l}\text { The Thai Excise Department recommended the Minister of Finance to allow imports of foreign cigarettes to safeguard } \\
\text { Thailand's Generalized System of Preferences privileges. }{ }^{86}\end{array}$ \\
\hline March 1989 (I) & $\begin{array}{l}\text { The Minister of Finance and some cabinet members, including the deputy prime minister, announced their support to } \\
\text { freely import and distribute foreign cigarettes. The Minister of Finance said, 'Of course, we have tried to discourage } \\
\text { smoking. But the fact is that people all around the world still smoke'. }{ }^{87} \text { The deputy prime minister added, 'Many } \\
\text { people are smoking foreign brands. They are here and have a market share already'. } \\
\text { Thai public health sector and TTM's union opposed this announcement immediately, and the Ministry of Finance } \\
\text { withdrew the market-opening proposal. }{ }^{88}\end{array}$ \\
\hline April $1989(\mathrm{I}, \mathrm{T})$ & $\begin{array}{l}\text { The US Cigarette Export Association (USCEA), formed by three major US cigarette companies (PM, RJR and Brown \& } \\
\text { Williamson (which was part of BAT)) in } 1981{ }^{33} \text { filed a Section } 301 \text { petition against Thailand on unfair trade practices for } \\
\text { foreign cigarettes to the US Trade Representatives (USTR), the US agency responsible for US bilateral and multilateral } \\
\text { trade policy. } \\
\text { USCEA and USTR have close relationships; for example, the head of the USTR (Clayton Yeutter), who helped the } \\
\text { USCEA open markets in Japan, Taiwan, Korea and Thailand between } 1985 \text { and } 1989 \text { later became a director of BAT in } \\
1993^{33} 89\end{array}$ \\
\hline July $1989(\mathrm{I}, \mathrm{T})$ & The USTR initiated the first consultation with the Thai government in Bangkok. ${ }^{34}$ \\
\hline September $1989(\mathrm{I}, \mathrm{T})$ & $\begin{array}{l}\text { The USTR held a public hearing in Washington, but the two parties did not reach mutual agreement because Thailand } \\
\text { viewed the dispute as a health and political issue, but the US viewed it as a trade action. }{ }^{34}\end{array}$ \\
\hline December $1989(\mathrm{I}, \mathrm{T})$ & The USTR referred the case to the GATT arbitration panel. ${ }^{34}$ \\
\hline October $1990(\mathrm{I}, \mathrm{T})$ & $\begin{array}{l}\text { GATT ruled that Thailand's import ban violated GATT but that non-discriminatory tobacco control legislation was } \\
\text { permissible as long as the laws applied to both domestic and foreign products. }{ }^{433}\end{array}$ \\
\hline August $1991(\mathrm{l}, \mathrm{T})$ & The Thai market opened to foreign cigarettes. ${ }^{33}$ \\
\hline
\end{tabular}

BAT, British American Tobacco; GATT, General Agreement on Tariffs and Trade; I, legal imports: a policy that allows foreign tobacco companies to import their tobacco products to Thailand; J, joint ventures: a business arrangement between a foreign tobacco company and the TTM to invest in a new tobacco factory in Thailand; L, licencing agreements: an agreement granted to the TTM to produce foreign cigarette brands; PM, Philip Morris; RJR, RJ Reynolds; T, trade sanctions: a TTC's international effort to open the Thai market via international trade organisations; TTC, transnational tobacco company; TTM, Thai Tobacco Monopoly.

resistance but expect to prevail'. ${ }^{35}$ PM USA's chair added, 'Thailand is a big market. The Thai monopoly currently sells 35 billion units. Add those units to those sold in Japan, Taiwan, and Korea, and you have a market almost as large as the US'. ${ }^{36}$

The USTR's position was that Thailand's restrictions aimed at protecting its monopoly rather than protecting public health. ${ }^{33}$ However, the Thai government raised concerns about the impact on public health via increased cigarette consumption from aggressive advertising and the resulting growth in preference for foreign cigarette brands, particularly among youth and women as had occurred in Japan and Taiwan following opening those markets to TTCs. ${ }^{4}$ These arguments were backed by several health organisations in the US and the region. ${ }^{4}$

When Thailand was forced to open the market by GATT in 1990 (with the first legal imported cigarettes arriving in August 1991), ${ }^{33}$ the Thai government established the Tobacco Consumption Control Office in the Ministry of Public Health to oversee all tobacco products and in
1992 passed two comprehensive tobacco control laws (the Tobacco Products Control Act and the Nonsmokers' Health Protection Act). ${ }^{37}$

\section{TTCs' preparation for market opening}

In November 1988, while waiting for the market to open during the USTR trade dispute, BAT focused on the possibility of a joint venture with TTM for manufactured cigarettes in Thailand. (BAT believed PM and RJR were unlikely to pursue joint ventures and instead concentrate on legalising imports) and supported cigarette smuggling with 'internal promotion' to raise brand awareness. ${ }^{32}$ BAT had monitored and sponsored several sport events to promote smuggled brands. ${ }^{67}$ BAT also continued supporting US pressure to legalise imports. ${ }^{32}$ BAT's director of BAT's Corporate Planning in London recommended that BAT 'Lobby for legal imports ..., but in a low key manner. PM is already spending a great deal of time and money on this, which BAT could not match' ${ }^{32}$ 
Table 2 Philip Morris (PM) action plan for the Thai market's opening, 1990-1992 38

\begin{tabular}{ll}
\hline Objective & Action plan \\
\hline 1. Achieve market access & $\begin{array}{l}\text { 1. Implement media relations plan (briefing the media, developing contacts, releasing information } \\
\text { and inviting journalists to sponsorships throughout the region). }\end{array}$
\end{tabular}

2. Partner with Thailand's Generalized System of Preferences beneficiaries such as jewellery and furniture associations to pressure the Thai government on opening the market (to avoid the US trade sanctions).

3. Support Thai government officials (on legalising imports) where appropriate and possible.

4. Support the US Trade Representative's efforts in negotiating market access.

5. Promote the US Cigarette Export Association's activities on regional and local publications.

6. Arrange reporters to visit PM's headquarters in Richmond, Virginia.

7.Publicise (the PM poll of December 1989) on public attitude towards allowing cigarette imports on 'freedom of choice' and benefits of free trade to economic development.

8.Publicise evidence that TTM's brands had higher tar than foreign brands.

2. Counter advertising ban 1. Collect data and publicise benefits of advertising and sponsorship, covering the number of sponsorship events held in Thailand.

2. Identify, develop and nurture local sports, arts or community organisations.

3. Continue and increase invitations to journalists and other relevant parties to PM sponsored regional events.

4. Hold at least one corporate sponsorship each year (if necessary though Kraft/General Foods (KGF) International, PM's food subsidiary).

\section{Develop PM's corporate image in the Thai financial community.}

6. Identify farmers' groups and encourage membership in the International Tobacco Growers' Association (a tobacco industry front group). ${ }^{9091}$

7. Develop and implement PM's plan through KGF to become involved in Green E-Sarn (the Northeastern region of Thailand) development plan (because this plan had received priority attention from the Thai government).

3. Counter public smoking 1. Extend the Asia ETS (Environmental Tobacco Smoke or secondhand smoke) consultants' restriction programme, which aimed to influence policymakers, media and the public on secondhand smoke and was supervised by the Covington \& Burling law firm in support of PM, RJR, BAT and $\mathrm{JTI}^{48}$ to Thailand and recruit local scientists.

\section{Arrange for an ETS study to be conducted in Thailand.}

3. Support pollution studies on indoor air quality in Bangkok.

4. Release information supportive to the industry to press.

5. Monitor the antismoking activists' activities.

6. Maintain social acceptability of smoking by publicising the benefits of accommodation (creation of smoking and non-smoking sections) ${ }^{92}$ and courtesy.

BAT, British American Tobacco; JTI, Japan Tobacco International; PM, Philip Morris; RJR, RJ Reynolds; TTM, Thai Tobacco Monopoly.

PM integrated planning activities for changes in the marketing and policy environment for cigarettes in Thailand into its broader plan for opening Asian markets. ${ }^{38}$ In December 1989, PM launched PM Asia's Corporate Affairs Plan for 1990-1992, which included its action plans for market access, marketing restrictions and public smoking restrictions in Thailand (table 2). ${ }^{38} \mathrm{PM}$ planned to approach all relevant stakeholders, including media, other industries that could be affected by the US trade sanctions, tobacco farmers, scientists and government officials. It prepared advertising and sponsorship activities to raise brands awareness and public acceptance, particularly with the government's projects through its food subsidiary to avoid criticism.
Advertising and sports sponsorships to raise brand awareness prior to market opening

TTCs initiated sports sponsorships in Thailand even though they knew advertising was illegal and their products could not be legally sold. ${ }^{6} \mathrm{PM}$ and RJR outstripped BAT in advertising and sponsorships in Thailand. ${ }^{39}$ PM had included Thailand in its 'Come to Marlboro Country' advertising campaign since $1976 .{ }^{40}$ Between 1986 and 1988, Marlboro sponsored badminton, motor racing, golf and Marlboro Country tours, and Winston involved with Thai boxing, golf, football, motor racing and badminton, which allowed them to advertise on TV, newspapers and billboards. ${ }^{39}$ Prior to 1987 , BAT was reluctant to initiate any sponsorships to avoid jeopardising its joint venture negotiations with TTM. ${ }^{6}$ 
In 1987, BAT began accelerating sponsorship activities as BAT's competitors were gaining wide market exposure for their brands through sponsorships. ${ }^{41}$ For example, Marlboro and Winston spent $£ 9000$ annually for their billboard advertising on the main highway to/from the airport, and Marlboro paid $\$ 700000$ for TV coverage in Thailand and surrounding countries of the Thomas Cup badminton and \$2.4 million for TV advertising of Marlboro Country tours. ${ }^{29}{ }^{41}$ BAT sponsored the 555 World Cup Badminton tournament in November 1987 and allocated $£ 200000$ for the 1988 advertising and sponsorship activities. ${ }^{614} 42$

The Thai government attempted to ban cigarette advertising in 1988 under the Consumer Protection Act of 1979. ${ }^{43}$ In April 1988, BAT UK's legal counsel confirmed with a Thai local law firm that the Consumer Protection Act was unclear, and there was no specific laws in Thailand prohibiting cigarette advertising on billboards or via sponsorships. ${ }^{44}$ During the negotiations between Thailand and the USTR between 1989 and 1990, TTCs continued advertising, especially through sports sponsorships and billboards. ${ }^{6}$

\section{LESSONS FOR TOBACCO INDUSTRY'S EFFORTS TO OVERTURN BANS ON ENDS}

TTCs' attempts to access the Thai cigarette market during the 1980s concentrated on political lobbying, as they then did in other Asian state monopoly-controlled markets . ${ }^{45}$ Like Korea, TTCs' attempted to enter Thailand through licencing agreements and joint ventures with the Thai government and switched to lobbying the US government to exert the trade sanction for market liberalisation after their local attempts failed. ${ }^{45}$ To increase market visibility and pressure the Thai government, TTCs also took advantage of unclear regulations about cigarette advertising to promote their products through advertising and sponsorship activities.

In Thailand, different TTCs used different approaches to lobby the government. BAT used its historic connections with TTM as the first TTC to manufacture cigarettes in Thailand during the $1930 \mathrm{~s},{ }^{11}$ which made BAT more cautious than other companies. BAT's risk-averse behaviour was also observed when it sought to re-enter China where it had been the largest foreign cigarette manufacturer before the country's market closed during the 1950s. ${ }^{46}$ In Thailand, BAT delayed advertising its products on Thai media several years after PM and RJR to avoid jeopardising its joint venture and licencing negotiations with TTM. BAT's local agents were not in top positions in politics or government officials. In contrast, PM approached people in high places such as the family of the deputy prime minister. ${ }^{29} \mathrm{PM}$ also had a strong connection with high-level politicians through its tobacco leaf business. ${ }^{47}$

While BAT was focusing on entering the Thai market to sell its products, PM's 1990-1992 action plan for obtaining access was more comprehensive and designed to impact the overall cigarette use environment. It had established strong relationships with reporters and relevant government officials, supported tobacco farmer groups, expanded the industry's International ETS Consultants Program ${ }^{48}$ to Thailand and used its food subsidiary to engage the government. ${ }^{38}$ PM's action plan continued after the market opened in 1992. After it added Thailand to the Asia ETS consultants programme in $1990,{ }^{48}$ it established close connections with the Chulabhorn Research Institute (a WHO Collaborating Centre for Capacity Building and Research in Environmental Health Science) during 1991-1999. ${ }^{49}$ PM's comprehensive plans and continuity resulted in the continuing growth in PM's market share since it legally entered the country $^{50}$ compared with other TTCs. As of 2019, PM held the largest market share of cigarettes in Thailand (50\%), whereas TTM held $43 \%$ of the share and other TTCs held only a minuscule market share. ${ }^{51}$

Lessons learnt from TTCs' attempts to penetrate Thailand's closed market are pertinent in 2021 as the TTCs pressure governments to allow sales of e-cigarettes and HTPs in countries where they are currently banned. ${ }^{52-54}$ Since Thailand banned e-cigarettes and HTPs in 2015, TTCs (particularly PM) and pro-e-cigarette groups (particularly ENDS Cigarette Smoke Thailand) have been lobbying the government to lift the ban. ${ }^{2}{ }^{54}$ They are repeating past strategies to open the cigarette market for the new tobacco products. ${ }^{2}$ Similar to earlier battles to open the cigarette market during the 1980 s, nonhealth government agencies and ministries were sympathetic to overturning the ban on e-cigarettes and HTPs. PM Thailand's managing director told the media in July 2019 that he had met with the Ministry of Commerce and the Excise Department and stated, 'We will continue to present fact-based, non-ideological studies and results from other countries [about e-cigarettes and HTPs] with the government. It would be silly to make an electric vehicle regulation without consulting automotive manufacturers, so there should be dialogue with the tobacco industry when crafting tobacco regulation, ${ }^{54}$

Although TTCs persistently lobbied the Thai government to lift the e-cigarette ban, as of January 2021, they had not succeeded. ${ }^{2}$ Lessons from the past suggest that if health advocates continue to prevail in these domestic policy debates, TTCs may turn to international trade pressure to force the government to open the market. The establishment of Foundation for a Smoke-Free World in 2017 by PMI initiated such international pressure, particularly fostering a strong connection between ENDS Cigarette Smoke Thailand and international vaping networks to intensify lobbying activities in Thailand. ${ }^{2} \mathrm{PM}$ also used decisions from US government's Food and Drug Administration that allowed PM's HTPs (IQOS) to sell and market as a 'modified risk product' in the US to promote the products in other countries. ${ }^{55}$

As in the past when TTCs exerted trade sanctions to open state monopoly cigarette markets (Japan, Taiwan, South Korea and Thailand) during the 1980s and early 
1990s, ${ }^{55}$ the next phase of opening closed markets for e-cigarettes and HTPs is possibly through international trade agreements. A former international trade manager of Japan Tobacco International and a current managing director of Trade Pacts (international consultant firm on international trade and investment) told the 2017 Global Forum on Nicotine (a pro-e-cigarette organisation) that a general ban on e-cigarettes was a highly trade restrictive measure and could be challenged under a number of World Trade Organization (WTO) provisions as these products and cigarettes may be 'like' under WTO law, and health justification was unlikely given good evidence on reduced risk to health. ${ }^{56}$ Moreover, in January 2017, provaping advocates, led by Clive Bates (a founder of consultancy and advocacy practice Counterfactual and attendee of the industry-funded Global Tobacco and Nicotine Forum since $2014^{58}$ ) offered eight proposals to the US to promote alternative or reduced risk tobacco products, and one of the proposals was to initiate complaints under WTO agreements about unjustified prohibitions of e-cigarettes outside the US. ${ }^{59}$

Trade agreements allow TTCs to pre-empt domestic authority over tobacco control policies where TTCs are weaker than public health advocates and transfer it to jurisdictions where business concerns dominate and TTCs' influence is strong. ${ }^{60}$ After market liberalisation in the 1980s, TTCs have exploited international trade agreements on several occasions such as interfering in tariff rates and excise taxes ${ }^{6162}$ and trying to block tobacco standardised packaging in many countries. ${ }^{63}$ (Other industries, including alcohol, pharma and food have adopted similar strategies to use international trade to oppose public health measures. ${ }^{60-66}$ ) It is likely that TTCs may turn to this venue to open Thai and other closed markets to e-cigarettes and HTPs if their local attempts fail.

\section{CONCLUSION}

TTCs attempted to penetrate Thailand's closed market beginning in the early 1980s using licencing agreements, joint ventures and legal imports combined with political lobbying along with heavy advertising, promotions and sponsorships by brands that could not be sold legally in Thailand at the time. Health advocates were able to block these efforts, assisted by tobacco worker union opposition to the TTCs getting involved with the TTM. After these domestic efforts failed, the TTCs used international trade law to force the Thai market open. Rather than simply capitulating to the TTCs, the Thai government established the Tobacco Consumption Control Office in the Ministry of Public Health to oversee all tobacco products and in 1992 passed two comprehensive tobacco control laws (the Tobacco Products Control Act and The Nonsmokers' Health Protection Act).

Mirroring these efforts in the 1980s and 1990s for cigarettes, as of 2021, TTCs were currently seeking to expand the market for e-cigarettes and HTPs through similar local pressure. ${ }^{2}$ While health advocates and government authorities succeeded in resisting domestic pressure, they should anticipate that the TTCs will attempt to use international trade law to force markets open for new tobacco products. Promoting and prioritising health both domestically and internationally to non-health and international trade agencies is important as these agencies generally prioritise trade over health.

As the tobacco companies continue to press into more LMIC, more attention should be given to past industry use of legal and administrative influences/measures to prevent this influence and establish science-based regulatory frameworks in LMIC. Health advocates should also persuade non-health agencies to maintain policies keeping new products out of these countries (especially low-income and middle-income countries) in accordance with recommendations of the International Union Against Tuberculosis and Lung Disease to prevent a new generation of addiction. ${ }^{67}$

Twitter Stanton A Glantz @ProfGlantz

Contributors RP developed the idea for this study, carried out the data collection and analysis and wrote and revised the manuscript. SAG helped develop the ideas for this study and revised and edited the manuscript.

Funding This work was supported by National Cancer Institute grant CA-087472 and the Faculty of Medicine Ramathibodi Hospital, Mahidol University, Thailand. The funding agencies played no role in study design; collection, analysis and interpretation of data; writing the report; or the decision to submit for publication.

Competing interests None declared.

Patient and public involvement Patients and/or the public were not involved in the design, or conduct, or reporting, or dissemination plans of this research.

Patient consent for publication Not required.

Provenance and peer review Not commissioned; externally peer reviewed.

Data availability statement All data relevant to the study are included in the article or uploaded as supplementary information.

Open access This is an open access article distributed in accordance with the Creative Commons Attribution Non Commercial (CC BY-NC 4.0) license, which permits others to distribute, remix, adapt, build upon this work non-commercially, and license their derivative works on different terms, provided the original work is properly cited, appropriate credit is given, any changes made indicated, and the use is non-commercial. See: http://creativecommons.org/licenses/by-nc/4.0/.

\section{ORCID iDs}

Roengrudee Patanavanich http://orcid.org/0000-0001-6277-3912

Stanton A Glantz http://orcid.org/0000-0003-4620-6672

\section{REFERENCES}

1 Bialous SA, Glantz SA. Heated tobacco products: another tobacco industry global strategy to slow progress in tobacco control. Tob Control 2018;27:s111-7.

2 Patanavanich R, Glantz S. Successful countering of tobacco industry efforts to overturn Thailand's ends ban. Tob Control 2020. doi:10.1136/tobaccocontrol-2020-056058. [Epub ahead of print: 23 Nov 2020] (published Online First: 2020/11/25).

3 Kaeokamnerd C. A financial analysis of Thailand tobacco monopoly. Chulalongkorn University, 1987.

4 Vatheesatokit P. Tailoring Tobacco Control Efforts to the Country: The Example of Thailand. In: Beyer JD, Brigden LW, eds. Tobacco control policy: strategies, successes, and Setbacks. 173. The World Bank, 2003.

5 MacKenzie R, Ross H, Lee K. 'Preparing ourselves to become an international organization': Thailand tobacco monopoly's regional and global strategies. Glob Public Health 2017;12:351-66.

6 MacKenzie R, Collin J, Sriwongcharoen K. Thailand--lighting up a dark market: British American tobacco, sports sponsorship and 
the circumvention of legislation. $J$ Epidemiol Community Health 2007;61:28-33.

7 MacKenzie R, Lee K, LeGresley E. To 'enable our legal product to compete effectively with the transit market': British American Tobacco's strategies in Thailand following the 1990 GATT dispute. Glob Public Health 2016;11:348-62.

8 Anderson SJ, McCandless PM, Klausner K, et al. Tobacco documents research methodology. Tob Control 2011;20 Suppl 2:ii8-11.

9 Applied Thematic Analysis. Thousand oaks, California: SAGE publications, Inc 2012.

10 The Secretariate of Cabinet. Cabinet Resolution - September 19, 1978 [การขออนุญาตนำเข้าและเป็นตัวแทนการจำหน่ายบุหรี่ต่างประเทศ] 1978. Available: http://www.cabinet.soc.go.th/soc/Program2-3. jsp?top_serl=56727\&key_word=\%E2\%C3\%A7\%A7\%D2\%B9\% C2\%D2\%CA\%D9\%BA\&owner_dep=\&meet_date_dd=\&meet_date _ $\mathrm{mm}=\&$ meet_date $\_y \mathrm{yyy}=\& d o c \_i \mathrm{~d} 1=\& d o c \_i d 2=\&$ meet_date_dd2 $=\&$ meet_date_mm2=\&meet_date_yyyy2=[Accessed 21 Apr 2020].

11 Where in the world. Tobacco Institute records; RPCI tobacco Institute and Council for tobacco research records; master settlement agreement. Available: https://www.industrydocuments. ucsf.edu/docs/rglm0027 [Accessed 9 Apr 2020].

12 British American Tobacco. BMB agenda Thursday 27th March 1986. March. 1986. British American Tobacco records. Available: https:// www.industrydocuments.ucsf.edu/docs/hpyv0194 [Accessed $10 \mathrm{Apr}$ 2020].

13 Devitre D. HM meeting with Thai Ambassador Kasemsri on 000215. February 15. 1984. Philip Morris records; master settlement agreement. Available: https://www.industrydocuments.ucsf.edu/ docs/phbn0114 [Accessed 20 Apr 2020].

14 BATCo, BAT, BATUKE. consumption of cigarettes in Thailand. August 16. 1982. British American Tobacco records. Available: https://www.industrydocuments.ucsf.edu/docs/gjlm0223 [Accessed 14 Apr 2020].

15 Morris P. Philip Morris incorporated proposal for a co-operative venture with the Thailand tobacco monopoly March. 1984. Philip Morris records; master settlement agreement. Available: https:// www.industrydocuments.ucsf.edu/docs/qhbn0114 [Accessed 8 Jun 2020].

16 Aitken J. [Memo from JM Aitken to WJ Dickson regarding trademark restrictions]. July 25. 1983. British American Tobacco Records. Available: https://www.industrydocuments.ucsf.edu/docs/gydh0212 [Accessed 13 Apr 2020].

17 British American Tobacco Company Limited, BATCo, BAT, et al. [Letter from M Norsworthy to Khun Anusorn Supmanu regarding Licensed Manufacture]. August 13. 1982. British American Tobacco Records. Available: https://www.industrydocuments.ucsf.edu/docs/ gpxl0224 [Accessed 13 Apr 2020].

18 Coburn R. [Letter from RJM Coburn to Nigel Stockley regarding visit to Bangkok]. February 07. 1983. British American Tobacco Records. Available: https://www.industrydocuments.ucsf.edu/docs/xklh0214 [Accessed 14 Apr 2020].

19 Coburn R. Thailand Visit - 11th December 1984. December 13. 1984. British American Tobacco Records. Available: https://www. industrydocuments.ucsf.edu/docs/njdh0212 [Accessed 13 Apr 2020].

20 Roberts P. [Note from P.J.N. Roberts regarding a project which is being considered to establish a factory outside Bangkok City]. April 27. 1981. British American Tobacco Records. Available: https:// www.industrydocuments.ucsf.edu/docs/mfyn0196 [Accessed $10 \mathrm{Apr}$ 2020].

21 Devitre D, Morris P. May 01. 1984. Philip Morris records; master settlement agreement.. Available: https://www.industrydocuments. ucsf.edu/docs/zhbn0114 [Accessed 13 Apr 2020].

22 BAT, BATCo, British American Tobacco. [An Article regarding Tobacco Firms Seek Venture with TTM]. March 15. 1983. British American Tobacco Records. Available: https://www. industrydocuments.ucsf.edu/docs/tkmj0224 [Accessed $10 \mathrm{Apr}$ 2020].

23 Rattakul B. December 11. 1984. Philip Morris records; master settlement agreement. Available: https://www.industrydocuments. ucsf.edu/docs/jnvj0111 [Accessed 21 Apr 2020].

24 Gembler A. Visit of Queen 000313. December 10. 1984. Philip Morris records; master settlement agreement. Available: https://www. industrydocuments.ucsf.edu/docs/shbn0114 [Accessed $21 \mathrm{Apr}$ 2020].

25 Planning meeting 850201. February 01. 1985. Philip Morris records; master settlement agreement. Available: https://www. industrydocuments.ucsf.edu/docs/qzxn0085 [Accessed 9 Jun 2020].

26 Vietnam Veterans Honored. May. 1985. tobacco Institute records; $\mathrm{RPCl}$ tobacco Institute and Council for tobacco research records; master settlement agreement. Available: https://www. industrydocuments.ucsf.edu/docs/hyjv0046 [Accessed 9 Jun 2020].

27 Philip Morris Companies Inc. Corporate Contributions Committee "Charitable" Contributions Status Report December 1985. December. 1985. Philip Morris Records; Master Settlement Agreement. Available: https://www.industrydocuments.ucsf.edu/ docs/sgxf0021 [Accessed 22 Jun 2020].

28 Snyder R. 850000 Board presentation - Asia Pacific. September 29. 1985. Philip Morris Records; Master Settlement Agreement. Available: https://www.industrydocuments.ucsf.edu/docs/zycc0145 [Accessed 12 Jun 2020].

29 Ivey T. Thailand Trip Notes 29th June - 2nd July. July 14. 1987. British American Tobacco Records. Available: https://www. industrydocuments.ucsf.edu/docs/hqfw0210 [Accessed $23 \mathrm{Apr}$ 2020].

30 Norsworthy M. Thailand. may 17. 1988. British American Tobacco records. Available: https://www.industrydocuments.ucsf.edu/docs/ rffw0210 [Accessed 30 Apr 2020].

31 White Group Limited,Kennedy D. [Letter from Des Kennedy to Michael Norsworthy regarding Chiengmai project]. September 02. 1988. British American Tobacco Records. Available: https://www. industrydocuments.ucsf.edu/docs/ltww0210 [Accessed 5 May 2020].

32 Norsworthy M. [Note from M Norsworthy to DG Heywood regarding visit to lan Ross]. November 10. 1988. British American Tobacco Records. Available: https://www.industrydocuments.ucsf.edu/docs/ msww0210 [Accessed 11 May 2020].

33 MacKenzie R, Collin J. "Trade policy, not morals or health policy": the US Trade Representative, tobacco companies and market liberalization in Thailand. Glob Soc Policy 2012;12:149-72.

34 United States General accounting office. dichotomy between U.S. tobacco export policy and antismoking initiatives. NSIAD-90-190 Washington DC1990, 2020. Available: https://www.gao.gov/ products/NSIAD-90-190 [Accessed 12 May 2020].

35 Webb W. 890000 PMI board presentation - Asia/Australia August 29. 1989. Philip Morris Records; Master Settlement Agreement. Available: https://www.industrydocuments.ucsf.edu/docs/lqfc0110 [Accessed 13 May 2020].

36 Resnik F, Morris P. Remarks by Frank E. Resnik Chaiman, Philip Morris USA Burley and dark leaf association Radisson Plaza hotel, Lexington, Kentucky Friday, 890922. September 22. 1989. Philip Morris records; master settlement agreement. Available: https:// www.industrydocuments.ucsf.edu/docs/hfcn0108 [Accessed 15 Jun 2020].

37 Chitanondh H. Defeat in Trade - Victory in Health. Bangkok, Thailand: Thailand Health Promotion Institute, 2001.

38 Morris P. Philip Morris Asia Corporate Affairs Plan 900000 - 920000. December. 1989. Philip Morris Records; Master Settlement Agreement. Available: https://www.industrydocuments.ucsf.edu/ docs/kfwc0110 [Accessed 15 Jun 2020].

39 Ivey TR. Thailand. April 08. 1988. British American Tobacco records. Available: https://www.industrydocuments.ucsf.edu/docs/khfw0210 [Accessed 20 Jul 2020].

40 Come to where the flavor is. Come to Marlboro country. 1976. Philip Morris records; master settlement agreement. Available: https://www. industrydocuments.ucsf.edu/docs/ztfh0025 [Accessed 20 Jul 2020].

41 Creative Directions Advertising Concepts Scripts, Berry. [A letter from Gerry to Mike Baker regarding 555 world cup badminton]. June 29. 1987. British American Tobacco Records. Available: https://www. industrydocuments.ucsf.edu/docs/kkbx0189 [Accessed 20 Jul 2020].

42 Thailand domestic. January 25. 1988. British American Tobacco records. Available: https://www.industrydocuments.ucsf.edu/docs/klfw0210 [Accessed 21 Jul 2020].

43 British-American Tobacco Company Limited. Korea: large firms want foreign cigarettes, 1988. Available: https://www.industrydocuments.ucsf. edu/docs/szww0210 [Accessed 21 Jul 2020].

44 Tilleke G. Thailand/Tobacco advertising, 1988. Available: https://www. industrydocuments.ucsf.edu/docs/qjcl0207 [Accessed 21 Jul 2020].

45 Lee S, Holden C, Lee K. Are transnational tobacco companies' market access strategies linked to economic development models? A case study of South Korea. Glob Public Health 2013;8:435-48.

46 Lee K, Gilmore AB, Collin J. Breaking and re-entering: British American tobacco in China 1979-2000. Tob Control 2004;13 Suppl 2:ii88-95.

47 BMB agenda 10th December 1984. December 10. 1984. British American Tobacco records. Available: https://www. industrydocuments.ucsf.edu/docs/srnd0194 [Accessed $13 \mathrm{Apr}$ 2020].

48 Barnoya J, Glantz SA. The tobacco industry's worldwide Ets consultants project: European and Asian components. Eur J Public Health 2006;16:69-77. 
49 Mackenzie R, Collin J. "A good personal scientific relationship": Philip Morris scientists and the Chulabhorn Research Institute, Bangkok. PLoS Med 2008;5:e238-48.

50 MacKenzie R, Lee K. PMI's proxy trade dispute with Thailand. Tob Control 2020;29:tobaccocontrol-2019-055374.

51 Passport: Euromonitor international. brand shares, 2020. Available: https://www.portal.euromonitor.com/portal/statisticsevolution/index [Accessed 2 Aug 2020].

52 E-Cigarettes industry appeals Gujarat $\mathrm{cm}$ to revoke ban: ZEENEWS, 2019. Available: https://zeenews.india.com/health/e-cigarettes-industryappeals-gujarat-cm-to-revoke-ban-2218263 [Accessed 22 Aug 2020].

53 Bogle A. Tobacco giants lobby PM and key MPS with pro-vaping message: ABC news, 2020. Available: https://www.abc.net.au/news/ science/2020-01-10/tobacco-industry-sought-vaping-meetings-withpm-and-cabinet/11855264 [Accessed 22 Aug 2020].

54 Hicks W. Phillip Morris international tries lobbying against e-cigarette ban, 2019. Available: https://www.bangkokpost.com/business/1720747/ pmi-tries-lobbying-against-e-cigarette-ban [Accessed 2 Aug 2020].

55 Lempert LK, Glantz S. Analysis of FDA's IQOS marketing authorisation and its policy impacts. Tob Control 2020. doi:10.1136/ tobaccocontrol-2019-055585. [Epub ahead of print: 29 Jun 2020] (published Online First: 2020/07/01).

56 Foltea M, Markitanova A. The "Likeness" of E-Vapour Products and Cigarettes in the World Trade Organization. European Journal of Risk Regulation 2017;8:342-63.

57 Gruszczynski L. Dr Foltea contributes to talks on regulating e-vapour products: trade Pacts, 2017. Available: https://tradepacts.com/news/ ccig-trade-protectionism-seminar-highlight-2/ [Accessed 15 Sep 2020].

58 Tobacco tactics. global forum on nicotine, 2020. Available: https:// tobaccotactics.org/wiki/global-forum-on-nicotine/ [Accessed 15 Sep 2020].

59 Bates C, Lehrer E, Sweanor D. Eight tobacco harm reduction proposals for the federal government: R street policy study, 2017. Available: https:// www.rstreet.org/wp-content/uploads/2017/01/81.pdf [Accessed 12 Sep 2020].

60 Crosbie E, Gonzalez M, Glantz SA. Health preemption behind closed doors: trade agreements and fast-track authority. Am J Public Health 2014;104:e7-13.

61 Eckhardt J, Holden C, Callard CD. Tobacco control and the world trade organization: mapping member states' positions after the framework convention on tobacco control. Tob Control 2016;25:692-8.

62 Holden C, Lee K. 'A major lobbying effort to change and unify the excise structure in six Central American countries': How British American Tobacco influenced tax and tariff rates in the Central American Common Market. Global Health 2011;7:15

63 Crosbie E, Eckford R, Bialous S. Containing diffusion: the tobacco industry's multipronged trade strategy to block tobacco standardised packaging. Tob Control 2019;28:195-205.

64 Labonté R, Crosbie E, Gleeson D, et al. USMCA (NAFTA 2.0): tightening the constraints on the right to regulate for public health. Global Health 2019;15:35.

65 Crosbie E, Carriedo A, Schmidt L. Hollow threats: transnational food and beverage companies' use of international agreements to fight Front-ofPack nutrition labeling in Mexico and beyond. Int $J$ Health Policy Manag 2020. doi:10.34172/ijhpm.2020.146. [Epub ahead of print: 10 Aug 2020].

66 Mialon M, Gaitan Charry DA, Cediel G, et al. 'I had never seen so many lobbyists': food industry political practices during the development of a new nutrition front-of-pack labelling system in Colombia. Public Health Nutr 2020:1-9.

67 International Union against tuberculosis and lung disease. where bans are best: why LMICs must Prohibit e-cigarette and HTP sales to truly tackle tobacco, 2020. Available: https://www.theunion.org/what-we-do/ publications/technical/english/TheUnion TobaccoControl E-CigPaper English_07.pdf [Accessed 29 Jun 2020].

68 Aitken J. Thailand. November 21. 1983. British American tobacco records. Available: https://www.industrydocuments.ucsf.edu/docs/ nlgl0205 [Accessed 4 Jun 2020].

69 Coburn R. Thailand - (Visited 25th - 27th January 1984). January 30. 1984. British American Tobacco Records. Available: https://www. industrydocuments.ucsf.edu/docs/gkdh0212 [Accessed 17 Apr 2020]

70 Aitken J. Meeting in Millbank 14th may, 1984. may 14. 1984. British American tobacco records. Available: https://www.industrydocuments. ucsf.edu/docs/gffp0205 [Accessed 17 Apr 2020]

71 Whist A, Morris P. February 13. 1984. Philip Morris records; master settlement agreement. Available: https://www.industrydocuments.ucsf. edu/docs/ghbn0114 [Accessed 8 Jun 2020].
72 BAT Limited,Coburn R. [Letter from RJM Coburn to JM Aitken regarding photo copy of Des Kennedy's letter to Mike Marjoram]. January 15. 1985. British American Tobacco Records. Available: https://www.industrydocuments.ucsf.edu/docs/gjdh0212 [Accessed 13 Apr 2020]

73 BGP. BMB agenda 24th October 1985. October 18. 1985. British American tobacco records. Available: https://www. industrydocuments.ucsf.edu/docs/rkhd0194 [Accessed $22 \mathrm{Apr}$ 2020].

74 Ministry turns down cigarette proposals. January 10. 1985. British American Tobacco records. Available: https://www. industrydocuments.ucsf.edu/docs/xjdh0212 [Accessed 13 Apr 2020].

75 The Bangkok Post. five options for TTM on foreign cigarettes. December 13. 1986. British American Tobacco records. Available: https://www. industrydocuments.ucsf.edu/docs/trfw0210 [Accessed 22 Apr 2020].

76 The Bangkok Post. US team to arrive tomorrow. December 17. 1986. British American Tobacco records. Available: https://www. industrydocuments.ucsf.edu/docs/zrfw0210 [Accessed 22 Apr 2020]

77 Downham. Thailand. January 08. 1987. British American Tobacco records. Available: https://www.industrydocuments.ucsf.edu/docs/ hmfw0210 [Accessed 23 Apr 2020].

78 Marjoram M. [Letter from MW Marjoram to EAA Bruell regarding ICD meeting]. September 23. 1987. British American Tobacco Records. Available: https://www.industrydocuments.ucsf.edu/docs/ypfw0210 [Accessed 23 Apr 2020].

79 Thorpe D. [Letter from DK Thorpe to Suthee regarding production of cigarettes]. August 11. 1987. British American Tobacco Records. Available: https://www.industrydocuments.ucsf.edu/docs/tpfw0210 [Accessed 23 Apr 2020].

80 Snyder RL, Morris P. [Letter from Richard L Snyder to Suthee Singhasaneh regarding Thai cigarette industry]. March 26. 1987. British American Tobacco Records. Available: https://www. industrydocuments.ucsf.edu/docs/nqfw0210 [Accessed 23 Apr 2020].

81 Price D. Thailand. February 01. 1988. British American Tobacco records. Available: https://www.industrydocuments.ucsf.edu/docs/ pkfw0210 [Accessed 25 Apr 2020].

82 Meeting with Cherdsak Romyanan - 9/5/88. May 09. 1988. British American Tobacco Records. Available: https://www. industrydocuments.ucsf.edu/docs/kkcl0207 [Accessed 27 Apr 2020].

83 Wichers J. Second meeting with Verapaul Mudamara at orchid hotel, Chiang Mai on 11th December 1987. December 21. 1987. British American Tobacco records. Available: https://www.industrydocuments. ucsf.edu/docs/smfw0210 [Accessed 24 Apr 2020].

84 BAT limited, Wichers J. meeting with (Thai consult) at Oriental hotel on 8th December 1987. December 21. 1987. British American Tobacco records. Available: https://www.industrydocuments.ucsf.edu/docs/ qmfw0210 [Accessed 23 Apr 2020].

85 BAT limited, Coburn R. Thailand. February 01. 1988. British American Tobacco records. Available: https://www.industrydocuments.ucsf.edu/ docs/tkfw0210 [Accessed 25 Apr 2020].

86 Kennedy D. Excise recommends cigarette imports. may 22. 1988. British American Tobacco records. Available: https://www.industrydocuments. ucsf.edu/docs/kzww0210 [Accessed 11 May 2020].

87 The Nation. Cigarette import takes a new turn. March 15. 1989. British American Tobacco records. Available: https://www.industrydocuments. ucsf.edu/docs/gtjd0210 [Accessed 12 May 2020].

88 The Nation. Public health against cigarette import. March 17. 1989. British American Tobacco records. Available: https://www. industrydocuments.ucsf.edu/docs/ptjd0210 [Accessed 10 Sep 2020]

89 Hannah L. Yeutter for BAT. January 13. 1993. British American Tobacco records. Available: https://www.industrydocuments.ucsf.edu/docs/ pqvn0201 [Accessed 22 Jun 2020].

90 INFOTAB, Bloxcidge JA. International tobacco growers' association (ITGA). October 11. 1988. British American Tobacco records. Available: https://www.industrydocuments.ucsf.edu/docs/pxxh0203 [Accessed 22 Jun 2020].

91 Marcotullio R, INTL RJR. International tobacco growers association (ITGA) June 15. 1989. RJ Reynolds records; master settlement agreement. Available: https://www.industrydocuments.ucsf.edu/docs/ pplw0084 [Accessed 22 Jun 2020].

92 Dearlove JV, Bialous SA, Glantz SA. Tobacco industry manipulation of the hospitality industry to maintain smoking in public places. Tob Control 2002;11:94-104. 